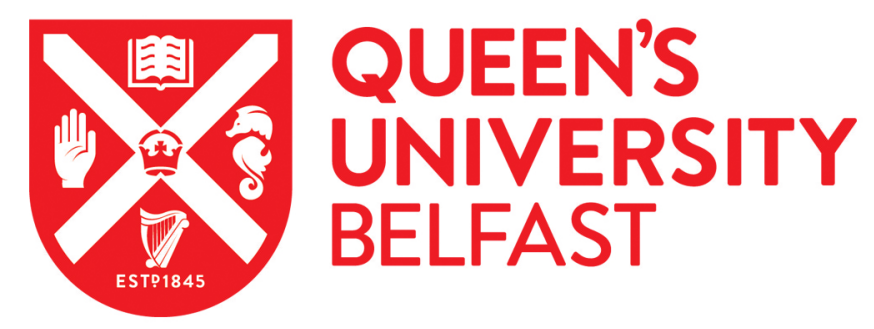

\title{
Effect of long-term fertilization on organic nitrogen forms in a calcareous alluvial soil on the North China Plain
}

Ju, X. T., Liu, X. J., Zhang, F. S., \& Christie, P. (2006). Effect of long-term fertilization on organic nitrogen forms in a calcareous alluvial soil on the North China Plain. Pedosphere, 16(2), 224-229.

https://doi.org/10.1016/S1002-0160(06)60047-7

\section{Published in:}

Pedosphere

Queen's University Belfast - Research Portal:

Link to publication record in Queen's University Belfast Research Portal

\section{General rights}

Copyright for the publications made accessible via the Queen's University Belfast Research Portal is retained by the author(s) and / or other copyright owners and it is a condition of accessing these publications that users recognise and abide by the legal requirements associated with these rights.

Take down policy

The Research Portal is Queen's institutional repository that provides access to Queen's research output. Every effort has been made to ensure that content in the Research Portal does not infringe any person's rights, or applicable UK laws. If you discover content in the Research Portal that you believe breaches copyright or violates any law, please contact openaccess@qub.ac.uk. 
Pedosphere 16(2): 224-229, 2006

ISSN 1002-0160/CN 32-1315/P

(C) 2006 Soil Science Society of China

Published by Elsevier Limited and Science Press

\title{
Effect of Long-Term Fertilization on Organic Nitrogen Forms in a Calcareous Alluvial Soil on the North China Plain*1
}

\author{
JU Xiao-Tang ${ }^{1}$, LIU Xue-Jun ${ }^{1, * 2}$, ZHANG Fu-Suo ${ }^{1}$ and P. CHRISTIE ${ }^{1,2}$ \\ ${ }^{1}$ Key Laboratory of Plant-Soil Interactions, Ministry of Education, College of Agricultural Resources and Environmental \\ Sciences, China Agricultural University, Beijing 100094 (China). E-mail: juxt@cau.edu.cn \\ ${ }^{2}$ Agricultural and Environmental Science Department, The Queen's University of Belfast, Belfast BT9 5PX (UK) \\ (Received October 12, 2005; revised January 13, 2006)
}

\begin{abstract}
In order to illustrate the change of nitrogen $(\mathrm{N})$ supply capacity after long-term application of manure and chemical fertilizer, as well as to properly manage soil fertility through fertilizer application under the soil-climatic conditions of the North China Plain, organic $\mathrm{N}$ forms were quantified in the topsoil with different manure and chemical fertilizer treatments in a 15-year fertilizer experiment in a Chinese calcareous alluvial soil. Soil total $N(T N)$ and various organic $N$ forms were significantly influenced by long-term application of chemical fertilizer and manure. TN, total hydrolysable $\mathrm{N}$, acid-insoluble $\mathrm{N}$, amino acid $\mathrm{N}$ and ammonium $\mathrm{N}$ in the soil increased significantly $(P<0.05)$ with increasing manure and fertilizer $\mathrm{N}$ rates, but were not influenced by increasing $P$ rates. Also, application of manure or $N$ fertilizer or $P$ fertilizer did not significantly influence either the quantity of amino sugar $\mathrm{N}$ or its proportion of $\mathrm{TN}$. Application of manure significantly increased $(P<0.05)$ hydrolysable unknown $\mathrm{N}$, but adding $\mathrm{N}$ or $\mathrm{P}$ did not. In addition, application of manure or $\mathrm{N}$ fertilizer or $\mathrm{P}$ fertilizer did not significantly influence the proportions of different soil organic $\mathrm{N}$ forms.
\end{abstract}

Key Words: chemical fertilizer, long-term fertilization, manure, North China Plain, soil organic nitrogen forms

\section{INTRODUCTION}

In most topsoils organic nitrogen (N) comprises more than $95 \%$ of soil total $\mathrm{N}$ (TN) (Stevenson, 1982a; Zhu, 1997). It contains old and new $\mathrm{N}$ fractions, some of which continually undergo microbially mediated mineralization and immobilization processes. Soil organic $\mathrm{N}$ can be divided into different forms according to chemical procedures proposed by Bremner (1965), and the chemical properties of different organic $\mathrm{N}$ forms in soil have some relationship with their availability to a crop after mineralizing (Stevenson, 1982a; Wu, 1986; Shen and Shi, 1990; Wang et al., 1991). There have been numerous reports in the literature concerning the effects of fertilization on quantity and composition of organic $\mathrm{N}$ forms in the soil (Keeny, 1964; Khan, 1971; Smith and Young, 1975; Stevenson, 1982a, b; Wu, 1986; Wang et al., 1991; Allison, 1997; Zhu, 1997; Liang et al., 2000), but the conclusions were quite contradictory. For instance, some studies showed that different fertilization management could significantly affect the quantity of different organic $\mathrm{N}$ forms; however the composition of these $\mathrm{N}$ forms was not significantly changed (Smith and Young, 1975; Stevenson, 1982b; Wang et al., 1991); other studies showed that not only the quantity but also the composition of organic $\mathrm{N}$ forms could be significantly affected by fertilization (Keeny, 1964; Khan, 1971; Liang et al., 2000).

Studies on soil $\mathrm{N}$ forms conducted in China have mostly concentrated on: 1) the composition of organic $\mathrm{N}$ forms in different types of soils or different regions (Zhang et al., 1984; Song, 1988; Zhou and Shi, 1992), 2) the relationship between organic $\mathrm{N}$ forms and their availability to crops (Shen and Shi, 1990), and 3) the changes of organic $\mathrm{N}$ forms after cultivation of virgin soil (Shi et al., 1992). Few studies have investigated the effect of fertilization on organic $\mathrm{N}$ forms (Shi and Zhou, 1995; Xu and Wu, 1991; Liang et al., 2000), especially after long-term fertilization.

*1 Project supported by the National Natural Science Foundation of China (Nos. 30390080 and 30370287).

${ }^{* 2}$ Corresponding author. E-mail: liu310@cau.edu.cn. 
The mineralization and immobilization of different organic $\mathrm{N}$ forms in soil is a slow process, thus long-term fertilization experiments are needed to analyze their pool changes. In order to illustrate the change of $\mathrm{N}$ supply capacity after long-term application of manure and chemical fertilizer as well as to properly manage soil fertility through fertilizer application under the soil-climatic conditions of the North China Plain, this study quantified organic $\mathrm{N}$ forms in topsoil with different treatments of manure and chemical fertilizer in a 15-year fertilization trial in a Chinese calcareous alluvial soil.

\section{MATERIALS AND METHODS}

A calcareous alluvial soil (FAO classification) was utilized in a 15-year fertilizer experiment at China Agricultural University's Changping Experimental Station. The climate is a warm-temperate, subhumid, continental monsoon type, with cold winters and hot summers. The average annual temperature is $11-12{ }^{\circ} \mathrm{C}$; the annual precipitation is $600-950 \mathrm{~mm}$; and the groundwater table is $2-3 \mathrm{~m}$. In 1984 at the beginning of the experiment, the soil chemical properties were: $\mathrm{pH}, 8.1$; organic matter, $13.1 \mathrm{~g} \mathrm{~kg}^{-1}$; total $\mathrm{N}, 0.71 \mathrm{~g} \mathrm{~kg}^{-1}$; Olsen-available $\mathrm{P}, 6.1 \mathrm{mg} \mathrm{kg}^{-1}$; and exchangeable $\mathrm{K}, 114 \mathrm{mg} \mathrm{kg}^{-1}$.

A manure and chemical fertilizer experiment was conducted with a split-plot design and three replications. The main treatments consisted of two levels of chicken manure: $0(\mathrm{~F})$ and $7500 \mathrm{~kg} \mathrm{ha} \mathrm{h}^{-1}$ year $^{-1}(\mathrm{M})$, while the sub-treatments had nine levels of combined chemical $\mathrm{N}$ and $\mathrm{P}$ fertilizers, whose $\mathrm{N}$ fertilizer and P fertilizer levels were $0(\mathrm{~N} 0), 135(\mathrm{~N} 1)$ and $270(\mathrm{~N} 2) \mathrm{kg} \mathrm{N} \mathrm{ha}^{-1} \mathrm{crop}^{-1}$, and $0(\mathrm{P} 0), 67.5$ (P1) and 135 (P2) $\mathrm{kg} \mathrm{P}_{2} \mathrm{O}_{5} \mathrm{ha}^{-1} \mathrm{crop}^{-1}$, respectively. Thus, the sub-treatments were N0P0, N0P1, $\mathrm{N} 0 \mathrm{P} 2, \mathrm{~N} 1 \mathrm{P} 0, \mathrm{~N} 1 \mathrm{P} 1, \mathrm{~N} 1 \mathrm{P} 2, \mathrm{~N} 2 \mathrm{P} 0, \mathrm{~N} 2 \mathrm{P} 1$, and N2P2 with or without chicken manure. Urea $(\mathrm{N}, 460$ $\left.\mathrm{g} \mathrm{kg}^{-1}\right)$ and triple calcium superphosphate $\left(\mathrm{P}_{2} \mathrm{O}_{5}, 460 \mathrm{~g} \mathrm{~kg}^{-1}\right)$ were used as the $\mathrm{N}$ and $\mathrm{P}$ fertilizers, respectively. Water and nutrient in the chicken manure varied from year to year with averages from 1984 to 1989 being $475 \mathrm{~g} \mathrm{~kg}^{-1}$ for water, and $134,12.5,9.4$ and $12.4 \mathrm{~g} \mathrm{~kg}^{-1}$ for organic matter, total $\mathrm{N}$, total $\mathrm{P}$ and total $\mathrm{K}$ (air-dry weight basis), respectively.

For 15 years the field experiment had a crop rotation of winter wheat-maize-maize with one winter fallow every two years. Consequently, crops in each plot had been harvested 21 times when the soil was sampled in 1999. Soil samples were collected at 0-20 cm from each plot, air-dried and ground to pass a 0.15 -mm sieve.

Soil TN and organic N forms were determined by the procedures described in Stevenson (1996). The effect of long-term fertilization on soil TN, total hydrolysable $\mathrm{N}$ and acid-insoluble $\mathrm{N}$; on soil ammonium $\mathrm{N}$ and amino acid $\mathrm{N}$; and on soil amino sugar $\mathrm{N}$ and hydrolysable unknown $\mathrm{N}$ was determined with an analysis of variance (ANOVA) where significance was compared by least significant difference (LSD) at the $5 \%$ level using the SAS statistical package (Version 6.12).

\section{RESULTS}

Soil total hydrolysable $N$, acid-insoluble $N$, and $T N$

Long-term chemical $\mathrm{N}$ or $\mathrm{P}$ fertilization combined with manure compared to that without manure significantly increased $(P<0.05)$ soil total hydrolysable $\mathrm{N}$, acid-insoluble $\mathrm{N}$, and TN by $11.4 \%, 27.3 \%$, and $15.2 \%$, respectively (Table I). Moreover, the average soil TN $\left(0.74 \mathrm{~g} \mathrm{~kg}^{-1}\right)$ in the plots receiving chemical fertilizer was slightly higher than the initial soil $\mathrm{TN}\left(0.71 \mathrm{~g} \mathrm{~kg}^{-1}\right)$ at the beginning of the experiment. Regardless of organic manure and $\mathrm{P}$ fertilizer applications, soil total hydrolysable $\mathrm{N}$, acidinsoluble $\mathrm{N}$, and $\mathrm{TN}$ with the highest $\mathrm{N}$ rate (N2) was significantly greater than that with N0 and N1. However, the increasing $\mathrm{P}$ rate did not significantly increase total hydrolysable $\mathrm{N}$, acid-insoluble $\mathrm{N}$ or TN in the soil (Table I).

Total hydrolysable $\mathrm{N}$ ranged from 489 to $653 \mathrm{mg} \mathrm{kg}^{-1}$ with an average of $601 \mathrm{mg} \mathrm{kg}^{-1}$ across the different treatments and formed the major part of $\mathrm{TN}$, comprising $69 \%-80 \%$ of TN with an average of $75 \%$ according to Fig. 1 . Acid-insoluble $\mathrm{N}$ ranged from 133 to $284 \mathrm{mg} \mathrm{kg}^{-1}$ with average of $200 \mathrm{mg}$ $\mathrm{kg}^{-1}$, comprising $20 \%-31 \%$ of TN with an average of $25 \%$ (Fig. 1). Nevertheless, the percentage of 
acid-insoluble $\mathrm{N}$ in $\mathrm{TN}(\mathrm{CV}=15 \%)$ varied more widely than that of total hydrolysable $\mathrm{N}(\mathrm{CV}=5 \%)$. TABLE I

Influence of long-term fertilization on soil total hydrolysable $\mathrm{N}$, acid-insoluble $\mathrm{N}$ and total $\mathrm{N}$ (mean of different treatments)

\begin{tabular}{llcc}
\hline Treatments $^{\text {a }}$ & Total hydrolysable N & Acid-insoluble N & Total N \\
\hline & & $\mathrm{mg} \mathrm{kg}^{-1}$ & $176 \mathrm{a}$ \\
F (N0, N1, N2, P0, P1, P2) & $568 \mathrm{a}^{\mathrm{b})}$ & $224 \mathrm{~b}$ & $744 \mathrm{a}$ \\
M (N0, N1, N2, P0, P1, P2) & $633 \mathrm{~b}$ & $173 \mathrm{a}$ & $857 \mathrm{~b}$ \\
N0 (F, M, P0, P1, P2) & $574 \mathrm{a}$ & $195 \mathrm{a}$ & $747 \mathrm{a}$ \\
N1 (F, M, P0, P1, P2) & $605 \mathrm{a}$ & $230 \mathrm{~b}$ & $800 \mathrm{a}$ \\
N2 (F, M, P0, P1, P2) & $624 \mathrm{~b}$ & $194 \mathrm{a}$ & $854 \mathrm{~b}$ \\
P0 (F, M, N0, N1, N2) & $602 \mathrm{a}$ & $210 \mathrm{a}$ & $796 \mathrm{a}$ \\
P1 (F, M, N0, N1, N2) & $606 \mathrm{a}$ & $195 \mathrm{a}$ & $816 \mathrm{a}$ \\
P2 (F, M, N0, N1, N2) & $594 \mathrm{a}$ & $789 \mathrm{a}$ \\
\hline
\end{tabular}

a) Chicken manure: $0(\mathrm{~F})$ and $7500(\mathrm{M}) \mathrm{kg} \mathrm{ha}^{-1}$ year $^{-1} ; \mathrm{N}$ fertilizer: $0(\mathrm{NO}), 135$ (N1), and 270 (N2) $\mathrm{kg} \mathrm{N} \mathrm{ha}^{-1} \mathrm{crop}^{-1}$; $P$ fertilizer: 0 (P0), 67.5 (P1), and 135 (P2) kg P $\mathrm{O}_{5} \mathrm{ha}^{-1} \mathrm{crop}^{-1} ; \mathrm{F}$ (No, N1, N2, P0, P1, P2) and M (No, N1, N2, P0, $\mathrm{P} 1, \mathrm{P} 2)$ : all treatments with $\mathrm{F}$ and $\mathrm{M}$, respectively; $\mathrm{N0}$ (F, M, P0, P1, P2), N1 (F, M, P0, P1, P2), and N2 (F, M, P0, $\mathrm{P} 1, \mathrm{P} 2)$ : all treatments with N0, N1, and N2, respectively; P0 (F, M, N0, N1, N2), P1 (F, M, N0, N1, N2), and P2 (F, $\mathrm{M}, \mathrm{N} 0, \mathrm{~N} 1, \mathrm{~N} 2$ ): all treatments with $\mathrm{P0}, \mathrm{P} 1$, and $\mathrm{P} 2$, respectively.

b) Mean values in a column followed by the same letter are not significantly different $(P=0.05)$ using LSD.

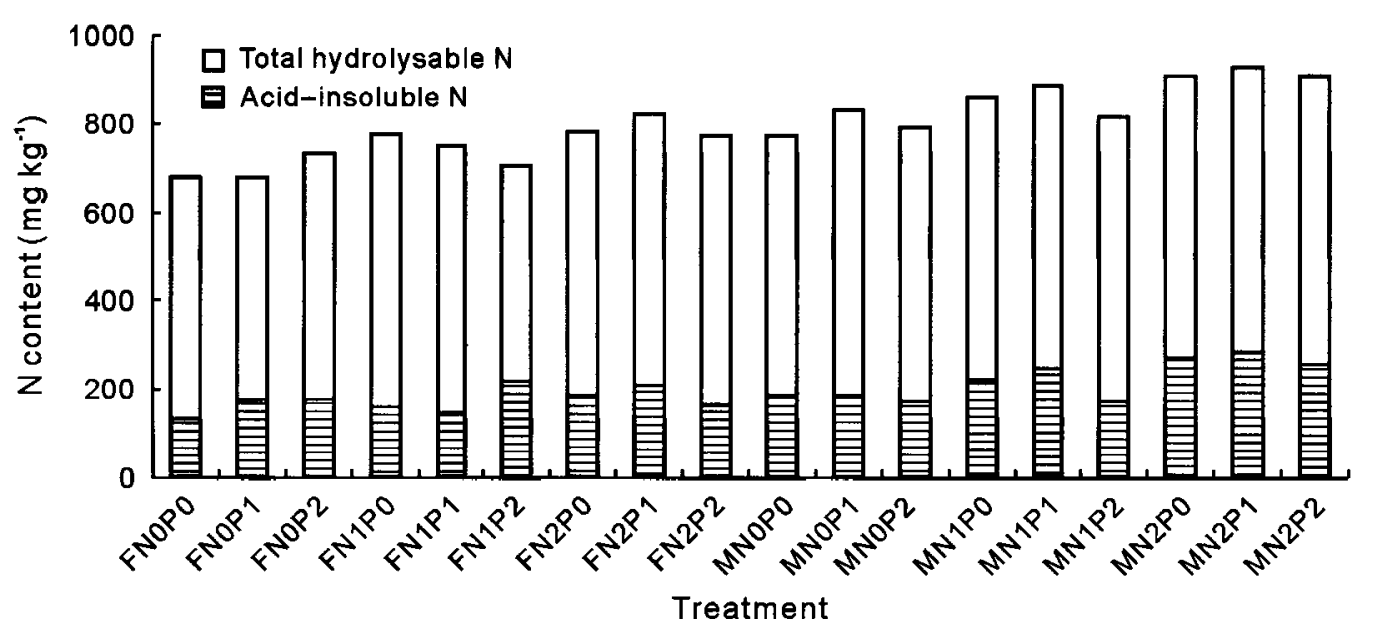

Fig. 1 Effect of long-term fertilization on soil total hydrolysable $N$ and acid-insoluble $N(n=3)$. F and M: chicken manure of 0 and $7500 \mathrm{~kg} \mathrm{ha}^{-1}$ year ${ }^{-1}$, respectively; N0, N1, and N2: $\mathrm{N}$ fertilizer of 0,135 , and $270 \mathrm{~kg} \mathrm{~N} \mathrm{ha}^{-1} \mathrm{crop}^{-1}$, respectively; $\mathrm{P} 0, \mathrm{P} 1$, and $\mathrm{P} 2$ : $\mathrm{P}$ fertilizer of $0,67.5$, and $135 \mathrm{~kg} \mathrm{P}_{2} \mathrm{O}_{5} \mathrm{ha}^{-1} \mathrm{crop}^{-1}$, respectively.

\section{Soil amino acid $N$ and ammonium $N$}

Amino acid $\mathrm{N}$ ranged from $148-224 \mathrm{mg} \mathrm{kg}^{-1}$ with an average of $182 \mathrm{mg} \mathrm{kg}^{-1}$ or $23 \%$ of $\mathrm{TN}$ according to Fig. 2. Also application of manure or $\mathrm{N}$ fertilizer significantly increased amino acid $\mathrm{N}$ (Table II). Ammonium $\mathrm{N}$ ranged from 102 to $212 \mathrm{mg} \mathrm{kg}^{-1}$ or $15 \%$ to $26 \%$ of TN (Fig. 2). The application of manure or $\mathrm{N}$ fertilizer significantly increased ammonium $\mathrm{N}$, whereas application of $\mathrm{P}$ fertilizer was not significant (Table II).

\section{Soil amino sugar $N$ and hydrolysable unknown $N$}

Amino sugar $\mathrm{N}$ ranged from 2.3 to $65 \mathrm{mg} \mathrm{kg}^{-1}$ with an average of $23 \mathrm{mg} \mathrm{kg}^{-1}$ (Fig. 2). Compared with other organic $\mathrm{N}$ forms, the amino sugar $\mathrm{N}$ of TN was lowest, being $0.3 \%-9.1 \%$ of TN with an average of $3.0 \%$, and showed the largest variation $(\mathrm{CV}=84 \%)$. With amino sugar $\mathrm{N}$, application of manure, $\mathrm{N}$ or P fertilizer did not significantly affect either the quantity (Table II) or the proportion of TN. 


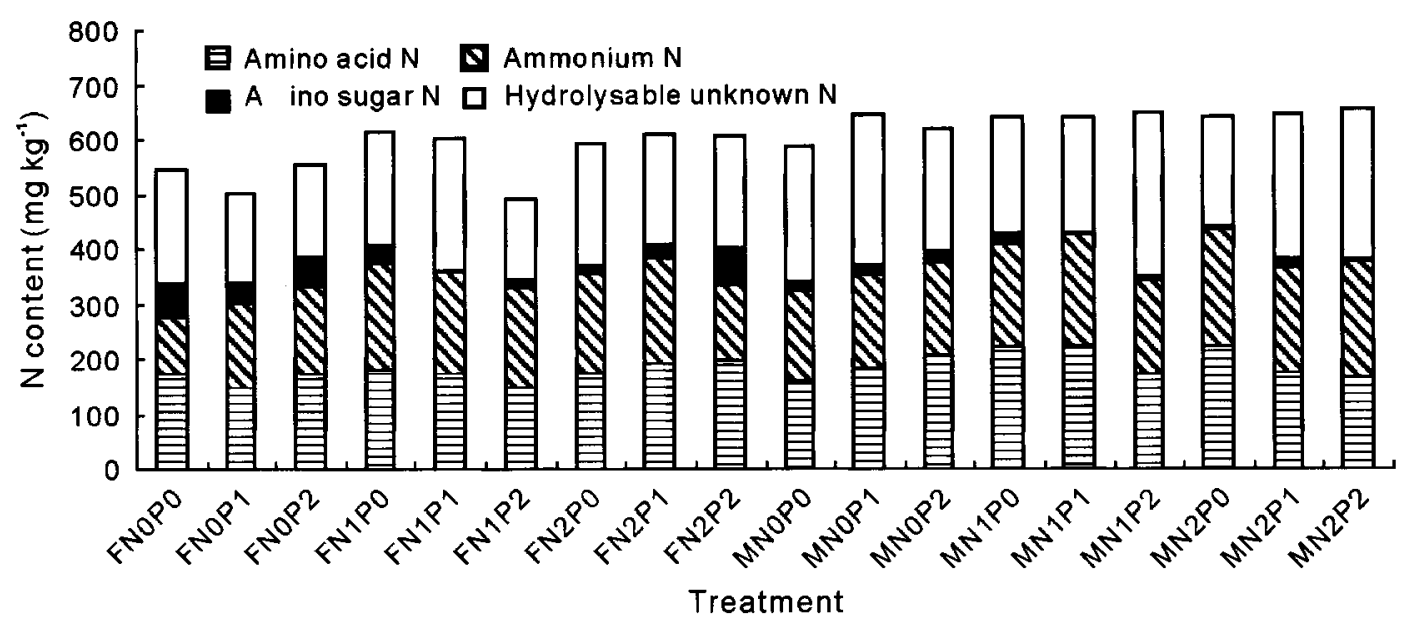

Fig. 2 Effect of long-term fertilization on soil organic $\mathrm{N}$ forms $(n=3) . \mathrm{F}$ and $\mathrm{M}$ : chicken manure of 0 and $7500 \mathrm{~kg} \mathrm{ha} \mathrm{a}^{-1}$ year $^{-1}$, respectively; $\mathrm{N} 0, \mathrm{~N} 1$, and N2: $\mathrm{N}$ fertilizer of 0,135 , and $270 \mathrm{~kg} \mathrm{~N}^{-1} \mathrm{crop}^{-1}$, respectively; P0, P1, and P2: P fertilizer of $0,67.5$, and $135 \mathrm{~kg} \mathrm{P}_{2} \mathrm{O}_{5} \mathrm{ha}^{-1} \mathrm{crop}^{-1}$, respectively.

\section{TABLE II}

Effect of long-term fertilization on soil amino acid $\mathrm{N}$, ammonium $\mathrm{N}$, amino sugar $\mathrm{N}$, and hydrolysable unknown $\mathrm{N}$ (mean of different treatments)

\begin{tabular}{lllll}
\hline Treatments $^{\mathrm{a}}$ & Amino acid N & Ammonium N & Amino sugar N & Hydrolysable unknown N \\
\hline & & & $\mathrm{mg} \mathrm{kg}^{-1}$ & \\
F (N0, N1, N2, P0, P1, P2) & $173 \mathrm{a}^{\mathrm{b})}$ & $164 \mathrm{a}$ & $34 \mathrm{a}$ & $197 \mathrm{a}$ \\
M (N0, N1, N2, P0, P1, P2) & $192 \mathrm{~b}$ & $184 \mathrm{~b}$ & $13 \mathrm{a}$ & $245 \mathrm{~b}$ \\
N0 (F, M, P0, P1, P2) & $174 \mathrm{a}$ & $152 \mathrm{a}$ & $34 \mathrm{a}$ & $213 \mathrm{a}$ \\
N1 (F, M, P0, P1, P2) & $186 \mathrm{~b}$ & $185 \mathrm{~b}$ & $13 \mathrm{a}$ & $220 \mathrm{a}$ \\
N2 (F, M, P0, P1, P2) & $187 \mathrm{~b}$ & $186 \mathrm{~b}$ & $22 \mathrm{a}$ & $229 \mathrm{a}$ \\
P0 (F, M, N0, N1, N2) & $188 \mathrm{a}$ & $172 \mathrm{a}$ & $25 \mathrm{a}$ & $216 \mathrm{a}$ \\
P1 (F, M, N0, N1, N2) & $183 \mathrm{a}$ & $180 \mathrm{a}$ & $17 \mathrm{a}$ & $227 \mathrm{a}$ \\
P2 (F, M, N0, N1, N2) & $177 \mathrm{a}$ & $170 \mathrm{a}$ & $27 \mathrm{a}$ & $220 \mathrm{a}$
\end{tabular}

a) Chicken manure: $0(\mathrm{~F})$ and $7500(\mathrm{M}) \mathrm{kg} \mathrm{ha}^{-1}$ year ${ }^{-1} ; \mathrm{N}$ fertilizer: 0 (N0), $135\left(\mathrm{~N} 1\right.$ ), and 270 (N2) $\mathrm{kg} \mathrm{N} \mathrm{ha}^{-1} \mathrm{crop}^{-1}$; $\mathrm{P}$ fertilizer: 0 (P0), 67.5 (P1), and 135 (P2) kg $\mathrm{P}_{2} \mathrm{O}_{5} \mathrm{ha}^{-1} \mathrm{crop}^{-1} ; \mathrm{F}$ (N0, N1, N2, P0, P1, P2) and M (N0, N1, N2, P0, $\mathrm{P} 1, \mathrm{P} 2)$ : all treatments with $\mathrm{F}$ and $\mathrm{M}$, respectively; $\mathrm{No}(\mathrm{F}, \mathrm{M}, \mathrm{P} 0, \mathrm{P} 1, \mathrm{P} 2)$, N1 (F, M, P0, P1, P2), and N2 (F, M, P0, $\mathrm{P} 1, \mathrm{P} 2)$ : all treatments with N0, N1, and N2, respectively; P0 (F, M, N0, N1, N2), P1 (F, M, N0, N1, N2), and P2 (F, $\mathrm{M}, \mathrm{N} 0, \mathrm{~N} 1, \mathrm{~N} 2$ ): all treatments with $\mathrm{P} 0, \mathrm{P} 1$, and $\mathrm{P} 2$, respectively.

b) Mean values in a column followed by the same letter are not significantly different $(P=0.05)$ using LSD.

Hydrolysable unknown $\mathrm{N}$ ranged from 147 to $296 \mathrm{mg} \mathrm{kg}^{-1}$ with an average of $221 \mathrm{mg} \mathrm{kg}^{-1}$ (Fig. 2) and contributed $21 \%-36 \%$ of TN with an average of $28 \%$. Application of manure significantly increased hydrolysable unknown $\mathrm{N}$, while $\mathrm{N}$ or $\mathrm{P}$ fertilization was not significant (Table II).

\section{Composition of different soil organic $N$ forms}

The proportions of soil organic $\mathrm{N}$ forms expressed as a percentage of soil total $\mathrm{N}$ are given in Table III. It could be seen that application of manure, $\mathrm{N}$ and $\mathrm{P}$ fertilizer did not significantly influence the composition of the different soil organic $\mathrm{N}$ forms.

\section{DISCUSSION}

The chemical forms of soil organic $\mathrm{N}$ are important in that they affect soil $\mathrm{N}$ availability to crops (Shen and Shi, 1990). Different fertilizer practices influence the quantity and composition of soil organic $\mathrm{N}$ forms. For example, after $\mathrm{N}$ application in their ${ }^{15} \mathrm{~N}$-tracer experiment, Allen et al. (1973) found that 
TABLE III

Effect of long-term fertilization on proportions of soil organic $\mathrm{N}$ forms expressed as a percentage of soil total $\mathrm{N}$ (mean of different treatments)

\begin{tabular}{|c|c|c|c|c|c|}
\hline Treatments $^{a)}$ & Amino acid $\mathrm{N}$ & Ammonium $\mathrm{N}$ & Amino sugar $\mathrm{N}$ & Hydrolysable unknown $\mathrm{N}$ & Acid-insoluble $\mathrm{N}$ \\
\hline & & & $\%$ & , & \\
\hline $\mathrm{F}(\mathrm{N} 0, \mathrm{~N} 1, \mathrm{~N} 2, \mathrm{P} 0, \mathrm{P} 1, \mathrm{P} 2)$ & $23.3 \mathrm{a}^{\mathrm{b})}$ & $22.1 \mathrm{a}$ & $4.5 \mathrm{a}$ & $26.5 \mathrm{a}$ & $23.6 \mathrm{a}$ \\
\hline $\mathrm{M}(\mathrm{N} 0, \mathrm{~N} 1, \mathrm{~N} 2, \mathrm{P} 0, \mathrm{P} 1, \mathrm{P} 2)$ & $22.4 \mathrm{a}$ & $21.5 \mathrm{a}$ & $1.5 \mathrm{a}$ & $28.5 \mathrm{a}$ & $26.1 \mathrm{a}$ \\
\hline No $(F, M, P 0, P 1, P 2)$ & $23.3 \mathrm{a}$ & $20.4 \mathrm{a}$ & $4.6 \mathrm{a}$ & $28.6 \mathrm{a}$ & $23.2 \mathrm{a}$ \\
\hline $\mathrm{N} 1(\mathrm{~F}, \mathrm{M}, \mathrm{P} 0, \mathrm{P} 1, \mathrm{P} 2)$ & $23.3 \mathrm{a}$ & $23.1 \mathrm{a}$ & $1.6 \mathrm{a}$ & $27.6 \mathrm{a}$ & $24.4 \mathrm{a}$ \\
\hline $\mathrm{N} 2(\mathrm{~F}, \mathrm{M}, \mathrm{P} 0, \mathrm{P} 1, \mathrm{P} 2)$ & $21.9 \mathrm{a}$ & $21.8 \mathrm{a}$ & $2.6 \mathrm{a}$ & $26.8 \mathrm{a}$ & $27.0 \mathrm{a}$ \\
\hline $\mathrm{PO}(\mathrm{F}, \mathrm{M}, \mathrm{N} 0, \mathrm{~N} 1, \mathrm{~N} 2)$ & $23.6 \mathrm{a}$ & $21.6 \mathrm{a}$ & $3.2 \mathrm{a}$ & $27.2 \mathrm{a}$ & $24.4 \mathrm{a}$ \\
\hline $\mathrm{P} 1(\mathrm{~F}, \mathrm{M}, \mathrm{N} 0, \mathrm{~N} 1, \mathrm{~N} 2)$ & $22.4 \mathrm{a}$ & $22.1 \mathrm{a}$ & $2.1 \mathrm{a}$ & $27.8 \mathrm{a}$ & $25.7 \mathrm{a}$ \\
\hline $\mathrm{P} 2(\mathrm{~F}, \mathrm{M}, \mathrm{N} 0, \mathrm{~N} 1, \mathrm{~N} 2)$ & $22.4 \mathrm{a}$ & $21.6 \mathrm{a}$ & $3.5 \mathrm{a}$ & $27.9 \mathrm{a}$ & $24.7 \mathrm{a}$ \\
\hline
\end{tabular}

a) Chicken manure: 0 (F) and $7500 \mathrm{~kg} \mathrm{ha}^{-1}$ year $^{-1}(\mathrm{M})$; $\mathrm{N}$ fertilizer: 0 (N0), 135 (N1), and 270 (N2) $\mathrm{kg} \mathrm{N} \mathrm{ha}^{-1} \mathrm{crop}^{-1}$; and $\mathrm{P}$ fertilizer: 0 (P0), 67.5 (P1), and 135 (P2) $\mathrm{kg} \mathrm{P}_{2} \mathrm{O}_{5} \mathrm{ha}^{-1} \mathrm{crop}^{-1}$; F (N0, N1, N2, P0, P1, P2) and M (No, N1, N2, P0, P1, P2): all treatments with $F$ and $M$, respectively; No (F, M, P0, P1, P2), N1 (F, M, P0, P1, P2), and N2 (F, M, $\mathrm{P0}, \mathrm{P} 1, \mathrm{P2}$ ): all treatments with No, N1, and N2, respectively; P0 (F, M, No, N1, N2), P1 (F, M, N0, N1, N2), and P2 (F, $\mathrm{M}, \mathrm{N0}, \mathrm{N} 1, \mathrm{~N} 2$ ): all treatments with $\mathrm{PO}, \mathrm{P} 1$, and $\mathrm{P} 2$, respectively.

b) Mean values in a column within each treatment followed by the same letters are not significantly different $(P=0.05)$ using LSD.

the proportions of amino acid $\mathrm{N}$ and amino sugar $\mathrm{N}$ in TN of soil humus increased, while acid-insoluble $\mathrm{N}$ and hydrolysable unknown $\mathrm{N}$ decreased. Wang et al. (1991) also showed that soil residual $\mathrm{N}$ from chemical $\mathrm{N}$ fertilizer mainly transferred to hydrolysable unknown $\mathrm{N}$ and amino acid $\mathrm{N}$, but soil residual $\mathrm{N}$ from manure mainly transformed into ammonium $\mathrm{N}$ and amino sugar $\mathrm{N}$. Furthermore, studies of Yang and Wang (1991) and Zhang et al. (1989) indicated that an application of manure led to an increase in amino acid $\mathrm{N}$ in soils; the results of $\mathrm{Xu}$ and $\mathrm{Wu}$ (1991) showed that application of urea without manure led to a decrease in total hydrolysable $\mathrm{N}$ in soil, but application of urea with manure led to an increase in total hydrolysable $\mathrm{N}$.

In the present study, average TN slightly increased over the 15-year period under chemical fertilizer application alone, perhaps reflecting the increase in returned crop residues (about $2.5 \mathrm{t} \mathrm{ha}^{-1}$ year $^{-1}$ ). Nevertheless, application of manure or $\mathrm{N}$ fertilizer significantly affected $\mathrm{TN}$ and organic $\mathrm{N}$ forms, while $\mathrm{P}$ fertilizer did not. The results also indicated that the combination of manure with chemical fertilizer increased the $\mathrm{N}$ supply potential to the crop, due to total hydrolysable $\mathrm{N}$, acid-insoluble $\mathrm{N}$ and $\mathrm{TN}$ being significantly increased. Additionally, the manure and $\mathrm{N}$ fertilizer applications also significantly increased amino acid $\mathrm{N}$, thereby increasing the $\mathrm{N}$ supply potential to crops because it was readily mineralizable. The ammonium $\mathrm{N}$ in the present study was slightly lower than the values obtained in other studies (Song, 1988; Liang et al., 2000). Additionally, a considerable amount of ammonium N, usually comprising up to $20 \%-35 \%$ of TN, will be produced during soil hydrolysable processes (Song, 1988; Liang et al., 2000).

On the other hand, application of manure, $\mathrm{N}$ and $\mathrm{P}$ fertilizer had no significant influence on the proportions of different soil organic $\mathrm{N}$ forms. This finding was in accord with the results of Liang et al. (2000) under similar soil conditions. In conclusion, long-term application of manure and $\mathrm{N}$ fertilizer effectively increased the content of soil $\mathrm{TN}$ and most organic $\mathrm{N}$ forms, thereby potentially increasing the soil $\mathrm{N}$ supply to crops.

\section{REFERENCES}

Allen, A. L., Stevenson, F. J. and Kurtz, L. T. 1973. Chemical distribution of residual fertilizer nitrogen in soil as revealed by nitrogen-15 studies. Journal of Environmental Quality. 2: 120-124.

Allison, F. J. 1997. Soil Organic Matter and Its Role in Crop Production. Development in Soil Science 3. Elsevier Press, Amsterdam. pp. 58-66. 
Bremner, J. M. 1965. Organic forms of nitrogen. In Black, C. A. (ed.) Methods of Soil Analysis. Part 2. American Society of Agronomy Incorporation, Madison. pp. 1238-1255.

Keeny, D. R. 1964. Effect of cultivation on the nitrogen distribution in soils. Soil Science Society of America Proceedings. 28: $653-656$.

Khan, S. V. 1971. Nitrogen fractions in a gray wooded soil as influenced by long-time cropping systems and fertilizers. Canadian Journal of Soil Science. 51: 431-437.

Liang, G. Q., Lin, B., Lin, J. X. and Rong, X. N. 2000. Effects of long-term fertilization on nitrogen fractions in calcareous Cambisols. Journal of Plant Nutrition and Fertilization (in Chinese). 6(1): 3-10.

Shen, Q. R. and Shi, R. H. 1990. Study on chemical composition of different organic nitrogen forms and its availability. Chinese Journal of Soil Science (in Chinese). 21: 54-57.

Shi, S. L. and Zhou, K. Y. 1995. Effects of fertilization on composition of nitrogen forms. Soils (in Chinese). 27(3): 138-140.

Shi, S. L., Wen, Q. X., Liao, H. Q. and Zhou, K. Y. 1992. Effects of cultivated virgin soils on distribution of nitrogen forms and composition of amino acid N. Soils (in Chinese). 24(1): 14-18.

Smith, S. J. and Young, L. B. 1975. Distribution of nitrogen forms in virgin and cultivated soils. Soil Science. 120(5): 354-360.

Song, Q. 1988. A study on organic nitrogen forms and characteristics in several types of soils in China. Acta Pedologica Sinica (in Chinese). 25(1): 95-110.

Stevenson, F. J. 1982a. Organic forms of soil nitrogen. In Stevenson, F. J. (ed.) Nitrogen in Agricultural Soils. Agron. Monpgr. 22. ASA, CSSA, and SSSA, Madison. pp. 67-122.

Stevenson, F. J. 1982b. Dynamics of soil nitrogen transformation. In Stevenson, F. J. (ed.) Humus Chemistry. John Wiley \& Sons, New York. pp. 93-119.

Stevenson, F. J. 1996. Nitrogen--organic forms. In Weaver, R. W., Angle, J. S. and Bottomley, P. S. (eds.) Methods of Soil Analysis. Part 2. Microbiological and Biochemical Properties. SSSA Book Series No. 5. SSSA and ASA, Madison. pp. $1185-1200$.

Wang, Y., Cai, D. T. and Shi, R. H. 1991. The availability of residual fertilizer nitrogen and its relationship with residual nitrogen forms and distribution in soil. Acta Pedologica Sinica (in Chinese). 30(1): 19-25.

Wu, G. Y. 1986. The forms, distribution and easily decomposing feature of soil organic nitrogen. Acta Pedologica Sinica (in Chinese). 17(2): 90-95.

$\mathrm{Xu}, \mathrm{C} . \mathrm{X}$. and Wu, S. R. 1991. Constitution of organic nitrogen in Lu soil and its change under condition of fertilization. Chinese Journal of Soil Science (in Chinese). 22(2): 54-56.

Yang, Z. Q. and Wang, W. M. 1991. The accumulation and release of carbon and nitrogen in soils after straw returning to field. Soils and Fertilizers (in Chinese). (5): 43-46.

Zhang, X. D., Xu, X. C. and Chen, E. F. 1989. Changes of amino acid content in soils as affected by application of pig manure. Chinese Journal of Soil Science (in Chinese). 20(6): 248-260.

Zhang, X. H, Dou, L. J. and Wen, Q. X. 1984. The quantity and composition of organic matter in different class particles in several paddy soils. Acta Pedologica Sinica (in Chinese). 21: 418-425.

Zhou, K. Y. and Shi, S. L. 1992. Distribution of nitrogen forms and composition of amino acid $\mathrm{N}$ in main types of soils in China. Soils (in Chinese). 24(6): 285-288.

Zhu, Z. L. 1997. Fate and Management of Fertilizer Nitrogen in Agroecosystem. In Zhu, Z. L., Wen, Q. X. and Freney, J. R. (eds.) Nitrogen in Soils of China. Kluwer Academic Publishers, Dordrecht/Boston/London. pp. $239-279$. 